\title{
Not all calcite ballast is created equal: differing effects of foraminiferan and coccolith calcite on the formation and sinking of aggregates
}

\author{
K. Schmidt ${ }^{1}{ }^{*}$, C. L. De La Rocha ${ }^{2}$, M. Gallinari ${ }^{2}$, and G. Cortese ${ }^{3}$ \\ ${ }^{1}$ Faculty of Mathematics and Natural Sciences, University of Groningen, the Netherlands \\ ${ }^{2}$ CNRS UMR 6539, Institut Universitaire Européen de la Mer, Université de Bretagne Occidentale, Plouzané, France \\ ${ }^{3}$ GNS Science, Lower Hutt, New Zealand \\ *now at: School of Environmental Science, University of East Anglia, United Kingdom
}

Correspondence to: C. L. De La Rocha (christina.delarocha@univ-brest.fr)

Received: 26 August 2013 - Published in Biogeosciences Discuss.: 10 September 2013

Revised: 21 November 2013 - Accepted: 2 December 2013 - Published: 9 January 2014

\begin{abstract}
Correlation between particulate organic carbon (POC) and calcium carbonate sinking through the deep ocean has led to the idea that ballast provided by calcium carbonate is important for the export of POC from the surface ocean. While this idea is certainly to some extent true, it is worth considering in more nuance, for example, examining the different effects on the aggregation and sinking of POC of small, non-sinking calcite particles like coccoliths and large, rapidly sinking calcite like planktonic foraminiferan tests. We have done that here in a simple experiment carried out in roller tanks that allow particles to sink continuously without being impeded by container walls. Coccoliths were efficiently incorporated into aggregates that formed during the experiment, increasing their sinking speed compared to similarly sized aggregates lacking added calcite ballast. The foraminiferan tests, which sank as fast as $700 \mathrm{~m} \mathrm{~d}^{-1}$, became associated with only very minor amounts of POC. In addition, when they collided with other, larger, foram-less aggregates, they fragmented them into two smaller, more slowly sinking aggregates. While these effects were certainly exaggerated within the confines of the rolling tanks, they clearly demonstrate that calcium carbonate ballast is not just calcium carbonate ballast - different forms of calcium carbonate ballast have notably different effects on POC aggregation, sinking, and export.
\end{abstract}

\section{Introduction}

The export of particulate organic carbon (POC) to the deep ocean prior to its oxidation back to carbon dioxide $\left(\mathrm{CO}_{2}\right)$ plays a critical role in the control of atmospheric concentrations of $\mathrm{CO}_{2}$ (Broecker, 1982; Kwon et al., 2009). But only a small fraction of the carbon fixed into POC in surface waters is exported below $1500 \mathrm{~m}$ and therefore excluded from exchange with the atmosphere for time periods longer than a few hundred years (Suess, 1980; Martin et al., 1987; Antia et al., 2001). This small fraction of material escapes from food webs efficient at retaining and oxidizing organic matter in the upper ocean, largely through the formation and sinking of aggregates larger than $1 \mathrm{~mm}$, including those made primarily of phytoplankton and detritus (Alldredge and Silver, 1988; Kiørboe, 2001; Turner, 2002; Boyd and Trull, 2007; Guidi et al., 2008; Burd and Jackson, 2009; McDonnell and Buesseler, 2010; Ebersbach et al., 2011). In the deep sea, sinking fluxes of POC and minerals (especially calcium carbonate) are strongly correlated, suggesting that ballasting by minerals also plays a role in POC export. This has led to two converse, but ultimately related suggestions. First, that because the density of POC is similar to that of seawater, POC is not dense enough to sink without ballast. Second, despite being denser than seawater, typical mineral particles in the ocean are too small to sink on their own; their export is dependent upon incorporation (with particulate organic matter) into aggregates larger than $1 \mathrm{~mm}$ (Deuser et al., 1981; Armstrong et al., 2002; François et al., 2002; Klaas and Archer, 2002; 
Passow 2004; Passow and De La Rocha 2006; De La Rocha et al., 2008; Thomalla et al., 2008; Engel et al., 2009a, b; Fischer and Karakaş, 2009; Iversen et al., 2010).

Incorporation of coccoliths (small scales of calcite produced by coccolithophores) into aggregates is known to decrease aggregate size but nonetheless increase aggregate sinking velocity (De La Rocha et al., 2008; Engel et al., 2009b; Iversen and Ploug, 2010; Sanders et al., 2010), supporting the notion that POC and minerals need each other to sink out of the surface ocean. However, not all pelagic calcium carbonate is in the form of coccoliths. For example, tests of planktonic forams make up roughly half of the calcium carbonate settling through the deep sea (Schiebel, 2002). Planktonic foraminiferan tests are large and, devoid of organic matter following gametogenesis, sink with speeds up to or even exceeding $1000 \mathrm{~m} \mathrm{~d}^{-1}$ (Honjo et al., 2008). The shear associated with such fast sinking should remove adhering organic matter, preventing its export from the upper ocean in association with sinking foraminiferan tests (Honjo et al., 2008). Thus while a significant portion of the calcite exported from the surface ocean should enable, enhance, or at least be associated with sinking fluxes of POC, the other significant portion of sinking calcite should have little influence over POC export.

In order to investigate the possibility that calcite in the form of coccoliths has a different effect on the character and sinking speed of aggregates than calcite in the form of foraminiferan tests, we allowed diatom aggregates to form in cylindrical rolling tanks in the presence of foraminiferan tests or coccoliths (or neither) and observed the difference in the number, size, mass, and sinking speed of the resulting aggregates.

\section{Materials and methods}

\subsection{Experimental set-up}

This experiment was conducted in a set of cylindrical $4.5 \mathrm{~L}$ tanks held in rotation on motorized roller tables so that particles could sink unimpeded by container walls for the duration of the experiment (Shanks and Trent, 1980; Passow and De La Rocha, 2006; Le Moigne et al., 2013). Tanks were filled with a culture of the diatom Chaetoceros gracilis that had been grown in $\mathrm{f} / 2$ medium (Guillard, 1975) made up in filtered seawater $(0.6 \mu \mathrm{m})$ for 7 days at $13^{\circ} \mathrm{C}$ under a light: dark cycle of $14 \mathrm{~h}: 10 \mathrm{~h}$. The cell concentration in the final volume was $1.5 \times 10^{5}$ cells $\mathrm{mL}^{-1}$. Three different treatments were set up in triplicate (although a number of these replicates were lost to accidents during the experiment): the phytoplankton culture on its own (Phyto), the culture plus $4.6 \mathrm{mg} \mathrm{L}^{-1}$ of cleaned coccoliths (Cocco), and the culture plus $4.6 \mathrm{mg} \mathrm{L}^{-1}$ of cleaned foraminiferan tests (Foram).

The suspension of coccoliths was prepared from Cretaceous (Maastrichtian) chalk from the cliffs of Rügen, Ger- many. The chalk was disaggregated, soaked overnight in a solution of $0.6 \%$ bleach (to remove remnant organic matter), and rinsed multiple times with Milli-Q water. The calcite was suspended in water, and larger particles were allowed to sink out. A similar suspension used by De La Rocha et al. (2008) consisted of coccoliths generally $<5 \mu \mathrm{m}$ in diameter and smaller calcium carbonate debris.

The foraminiferan tests that were used in the Foram treatment were taken from a Deep Sea Drilling Project (DSDP) sample, officially discarded due to a buckled core liner. The material, Pliocene in age, came from Leg 29 (Station $284 ; 10-6 ; 140-150 \mathrm{~cm}$ ) from the Challenger Plateau $\left(40^{\circ} 30.48^{\prime} \mathrm{S}, 167^{\circ} 40.81^{\prime} \mathrm{E} ; 1066 \mathrm{mb}\right.$.s.l. $)$ west of New Zealand. This material was sieved and intact foraminiferan tests $>250 \mu \mathrm{m}$ in size were selected via picking with the aid of a binocular microscope. Like the coccoliths, the foraminiferan tests were cleaned by soaking overnight in $0.6 \%$ bleach followed by multiple rinses with Milli-Q water.

The concentration of calcite used, $4.6 \mathrm{mg} \mathrm{L}^{-1}$, is higher than concentrations of calcium carbonate observed, for example, during coccolithophore blooms, which are on the order of 0.4 to $0.8 \mathrm{mg} \mathrm{CaCO}_{3}$ per liter (Harlay et al., 2011). But this mass represents a relatively low number compared to how much calcite might be encountered in $48 \mathrm{~h}$ (the length of the experiment) by an aggregate sinking 100 to $500 \mathrm{~m}$ per day.

Following filling with the phytoplankton culture and, where applicable, addition of the calcium carbonate, the rolling tanks were immediately transferred onto the roller tables and rotated at $3 \mathrm{rpm}$. The tanks were kept in the dark at $16^{\circ} \mathrm{C}$ for $48 \mathrm{~h}$ to allow aggregates to form prior to sampling.

\subsection{Sampling and analysis}

At the beginning of the experiment $\left(\mathrm{T}_{0}\right)$, samples of material suspended in the water in the tanks were taken for particulate organic carbon and nitrogen (POC and PON), particulate inorganic carbon (PIC), transparent exopolymer particles (TEP), and biogenic silica $\left(\mathrm{bSiO}_{2}\right)$.

After $48 \mathrm{~h}$ of rotation $\left(\mathrm{T}_{\mathrm{f}}\right)$, each tank was taken down individually from the roller table and put to rest flat side down. Each tank was left rotating on the table until it was its turn to be sampled from. After aggregates were allowed to settle for roughly $15 \mathrm{~min}$, a photograph of the tank bottom was made for later counting and sizing of the aggregates using the ImageJ program (Version $1.44 \mathrm{p}$ ). Due to the amount of work involved and the loss of some replicate tanks for some of the treatments, this counting and sizing was done from one tank for each treatment. At least 10 aggregates per tank were removed by hand using a plastic, $10 \mathrm{~mL}$, serological pipette whose conical tip had been sawed off. The length and width of these aggregates was noted against a grid. These aggregates were then gently transferred into a graduated glass cylinder that was $8 \mathrm{~cm}$ in diameter and filled 
with filtered seawater at the temperature of the controlledtemperature room the roller tables were in. The time the aggregates needed to sink a marked distance $(4 \mathrm{~cm})$ that was more than $7 \mathrm{~cm}$ below the aggregate introduction point was timed using a stopwatch. After the sinking speed measurements for each tank were completed, all visible aggregates $>1 \mathrm{~mm}$ in the tank were collected and combined to form a slurry which was subsampled for POC, PON, PIC, TEP, and $\mathrm{bSiO}_{2}$. Aggregates $<1 \mathrm{~mm}$ were not quantitatively sampled because they represented a small part of the total aggregate pool and were difficult to see and to collect. The exception to this is the small aggregates containing a foraminiferan test; those, being easy to locate and collect, were quantitatively sampled. The material remaining in suspension in the tank (termed background water in this manuscript) was also sampled for these parameters.

Concentrations of POC and PON were determined according to Lorrain et al. (2003). Samples of 5-20 mL were filtered gently $(<150 \mathrm{~mm} \mathrm{Hg})$ onto pre-weighed, pre-combusted $(4 \mathrm{~h}$ at $500^{\circ} \mathrm{C}$ ) $\mathrm{GF} / \mathrm{F}$ filters (Whatman) and rinsed once with Milli-Q water to remove seasalt. Filters were dried at $60^{\circ} \mathrm{C}$ for at least $24 \mathrm{~h}$ and stored until analysis. Immediately prior to analysis, filters were weighed again and then decarbonated via fuming with concentrated hydrochloric acid in a desiccator for $4 \mathrm{~h}$. Samples were then dried overnight at $60^{\circ} \mathrm{C}$ and analyzed with a Perkin-Elmer $2400 \mathrm{CHN}$ elemental analyzer using atropine ( $\geq 99 \%$, Sigma Aldrich) as the calibration standard.

Particulate inorganic carbon (PIC) was sampled and analyzed as described in Poulton et al. (2006). Samples of 5$20 \mathrm{~mL}$ were gently filtered onto pre-weighed polycarbonate filters $(0.4 \mu \mathrm{m}$, Cyclopore $)$ and rinsed with Milli-Q water to remove salts then dried at $60^{\circ} \mathrm{C}$ for $24 \mathrm{~h}$. Dried filters were digested in $10 \mathrm{~mL}$ of $0.4 \mathrm{~N} \mathrm{HNO}_{3}$ for $48 \mathrm{~h}$. After filtration, the filtrate was analyzed for $\mathrm{Ca}$ (assuming that all PIC was present as $\mathrm{CaCO}_{3}$ ) and $\mathrm{Na}$ (to verify that there was no $\mathrm{Ca}$ contribution from seasalt) by ICP-AES (HORIBA Jobin YVON / ULTIMA 2).

The abundance of transparent exopolymer particles (TEP) was determined following the spectrophotometric method of Passow and Alldredge (1995). TEP was collected by filtering $5-50 \mathrm{~mL}$ of sample under low pressure $(<150 \mathrm{~mm} \mathrm{Hg})$ onto polycarbonate filters $(0.4 \mu \mathrm{m}$, Cyclopore $)$ and then stained with $500 \mu \mathrm{L}$ of an Alcian blue solution and rinsed with Milli$\mathrm{Q}$ water. Filters were folded and stored frozen until analysis. For analysis, filters were soaked in $6 \mathrm{~mL}$ of $80 \% \mathrm{H}_{2} \mathrm{SO}_{4}$ for $2 \mathrm{~h}$ to dissolve the Alcian blue they had retained. The absorbance of the resulting solution was measured at $787 \mathrm{~nm}$ using a PRIM Light and Advanced Spectrophotometer (Secomam). Unfortunately, we were unable to calibrate the Alcian blue solution against xanthan gum. Values for TEP are therefore reported in units of absorption at $787 \mathrm{~nm}$ per volume of sample, allowing comparison among the treatments in this experiment.
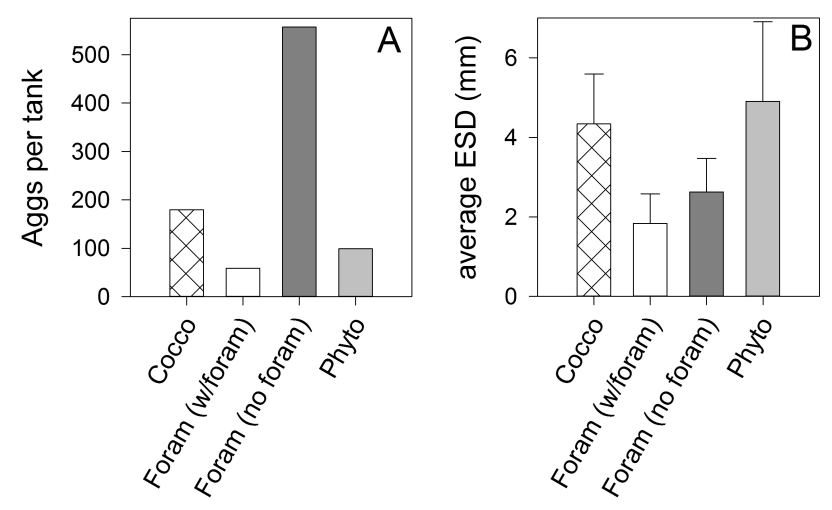

Fig. 1. Average (A) number and (B) equivalent spherical diameter (ESD) of the different types of aggregates formed in Tank 11 (Phyto), Tank 7 (Foram), and Tank 12 (Cocco), the three tanks from which counts are available.

Biogenic silica $\left(\mathrm{bSiO}_{2}\right)$ was determined according to a method modified from Ragueneau and Tréguer (1994). Samples of $5-50 \mathrm{~mL}$ were filtered onto polycarbonate filters $\left(0.4 \mu \mathrm{m}\right.$, Cyclopore) and dried at $60^{\circ} \mathrm{C}$. Biogenic silica was digested in $0.2 \mathrm{M} \mathrm{NaOH}$ at $100^{\circ} \mathrm{C}$ in polymethylpentene (PMP) tubes. The reaction was stopped after $1 \mathrm{~h}$ by addition of $1 \mathrm{M} \mathrm{HCl}$. After cooling, samples were centrifuged for $15 \mathrm{~min}$ at $3000 \mathrm{rpm}$ and the supernatant retained for measurement of dissolved silicon concentration (DSi). DSi was measured with a Shimadzu UV 1700 spectrophotometer following the molybdate blue method of Mullin and Riley (1965).

\section{Results}

Aggregates formed in all of the rolling tanks during the experiment (Figs. 1-2). The least number of aggregates formed in the Phyto tanks (99 aggregates in Tank 11, the Phyto tank that was counted). Almost twice as many aggregates formed in the Cocco tanks (180 Cocco aggregates in Tank 12, the Cocco tank that was counted). The Foram tanks, which held the greatest number of aggregates, contained two different types of aggregates (Figs. 1-2). In Tank 7, the Foram tank which was counted, there were 59 tiny aggregates that consisted of a single foraminiferan test plus a small amount of particulate organic matter. These aggregates will be referred to as Foram (w/foram) aggregates. There were also $557 \mathrm{ag}-$ gregates that lacked a foraminiferan test. These aggregates will be referred to as Foram (no foram) aggregates.

Per aggregate the Phyto aggregates contained more POC, $\mathrm{PON}, \mathrm{bSiO}_{2}$, and TEP than aggregates in the other treatments (Fig. 3), although with an average size of $4.9 \pm 2.0 \mathrm{~mm}$, they were not significantly larger than the Cocco aggregates, which averaged $4.3 \pm 1.3 \mathrm{~mm}$ (Figs. 1-2). Unsurprisingly, the Cocco and the Foram (w/foram) aggregates contained notably greater amounts of PIC than the Phyto aggregates and the Foram (no foram) aggregates (Fig. 4a). 


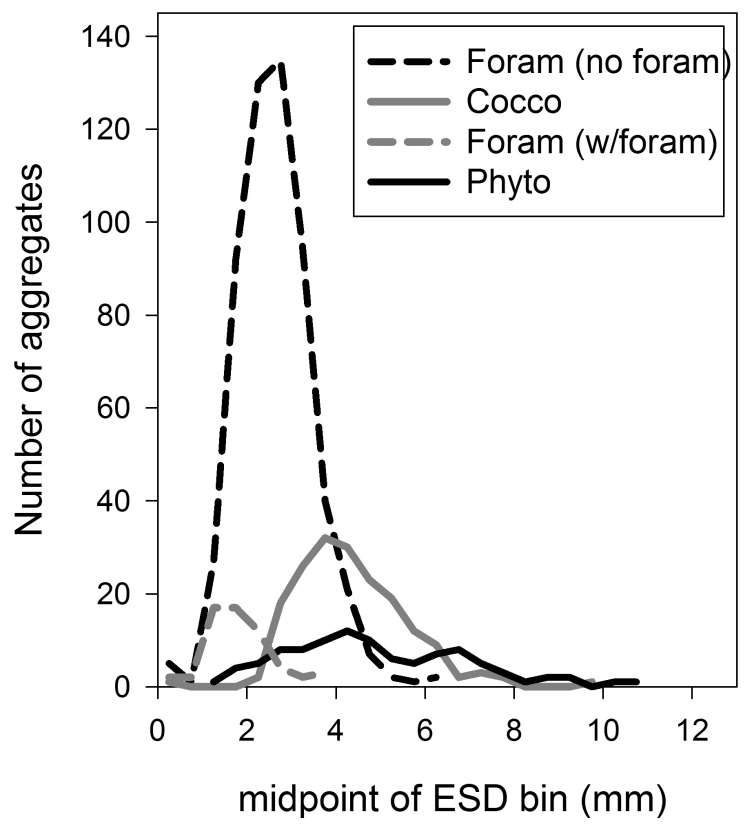

Fig. 2. Frequency of ESDs of aggregates inTank 11 (Phyto), Tank 7 (Foram), and Tank 12 (Cocco). The ESD bins are $0.5 \mathrm{~mm}$ wide.

Because aggregates formed during the experiment from both suspended and sinking material, concentrations of POC, $\mathrm{PON}, \mathrm{bSiO}_{2}$, PIC, and TEP suspended in the background water were lower at the end of the experiment than at the beginning (Figs. $4 \mathrm{~b}$ and 5). Because the foraminiferan tests sank immediately to the bottom of the tanks when the tanks were not in rotation, concentrations of suspended PIC in the Foram treatment were negligible at both $\mathrm{T}_{0}$ and $\mathrm{T}_{\mathrm{f}}$ (Fig. $4 \mathrm{~b}$ ) despite the addition of $4.6 \mathrm{mg} \mathrm{L}^{-1}$ of foraminiferan calcite to these tanks. In contrast, the initial concentration of suspended PIC in the Cocco tanks $\left(0.49 \pm 0.02 \mathrm{mg} \mathrm{L}^{-1}\right)$ is barely distinguishable from the total amount of PIC known to be added as coccoliths ( $4.6 \mathrm{mg} \mathrm{L}^{-1}$ of $\mathrm{CaCO}_{3}=0.55 \mathrm{mg} \mathrm{L}^{-1}$ of PIC), indicating that the coccoliths remained in suspension for a time even in the absence of rotation.

Within the scatter between replicate tanks and the precision of the measurements, there were not significant differences in the ratios of $\mathrm{POC}$ to $\mathrm{bSiO}_{2}$, to PON, or to TEP in suspension at the beginning of the experiment and in the aggregates that had formed by the end (Fig. 6). Likewise, the difference in the POC to dry weight ratio of the calcitecontaining aggregates was not much greater than the variability within aggregate types, although there were hints of differences between aggregate types. The Foram (w/foram) aggregates were $5 \pm 1 \%$ POC by weight compared to $11 \pm 1 \%$ for the Cocco aggregates. In contrast, Phyto aggregates, lacking in added PIC ballast, were $17 \pm 4 \%$ POC by weight. Unsurprisingly, ratios of POC to PIC were significantly lower in the Cocco and Foram (w/foram) aggregates than in the Phyto and Foram (no foram) aggregates (Fig. 7).
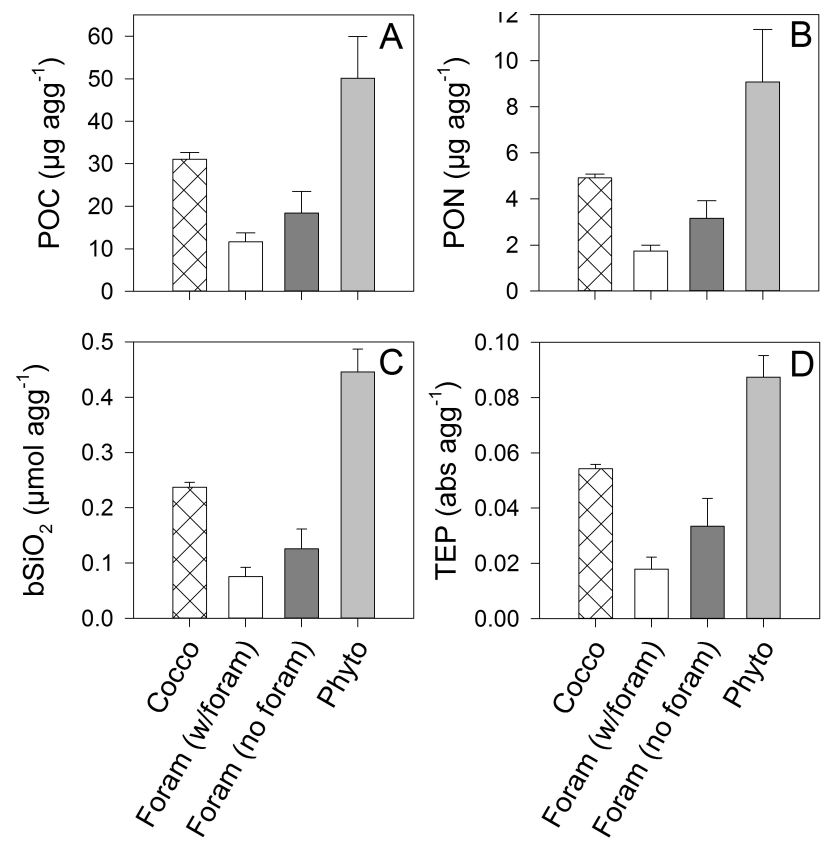

Fig. 3. Average content of (A) POC, (B) $\mathrm{PON}$, (C) $\mathrm{bSiO}_{2}$, (D) TEP per aggregate for the different types of aggregates formed.
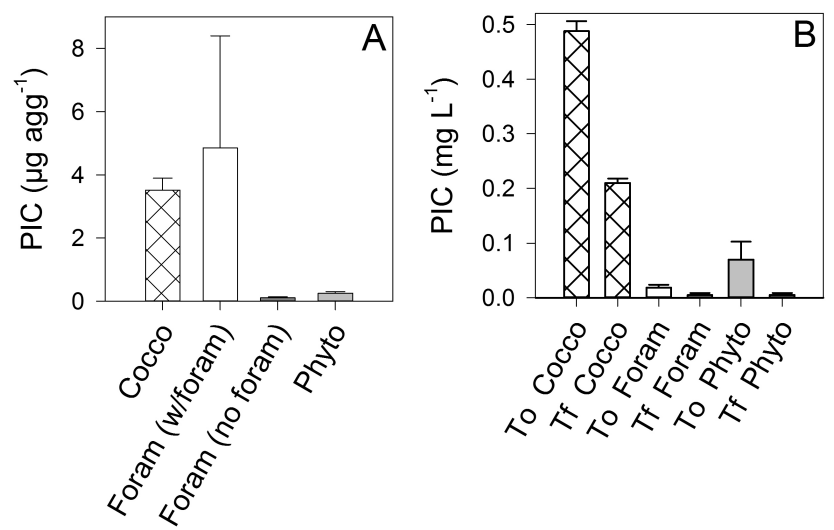

Fig. 4. Concentrations of PIC (in $\mu \mathrm{g} \mathrm{C}$ ) in (A) aggregates at the end of the experiment and (B) suspended in the water in the tanks of the different treatments at the beginning $\left(\mathrm{T}_{0}\right)$ and end $\left(\mathrm{T}_{\mathrm{f}}\right)$ of the experiment.

The different types of aggregates had different relationships between their size (equivalent spherical diameter, ESD) and sinking speed (Fig. 8). The aggregates that formed in the Foram tanks without incorporating foraminiferan tests (the Foram (no foram) aggregates) sank the most slowly, due to the lack of added calcite ballast and to their relatively small size (Fig. 8). Together with the similar calcite-free Phyto aggregates, they showed a relationship between ESD and sinking speed $\left(\mathrm{W}\right.$, in $\left.\mathrm{m} \mathrm{d}^{-1}\right)$ of $\mathrm{W}=70(\mathrm{ESD})^{1.00} \mathrm{~m} \mathrm{~d}^{-1}\left(r^{2}=\right.$ 0.82). The Cocco aggregates sank faster for a given ESD than the Phyto and Foram (no/foram aggregates), showing 

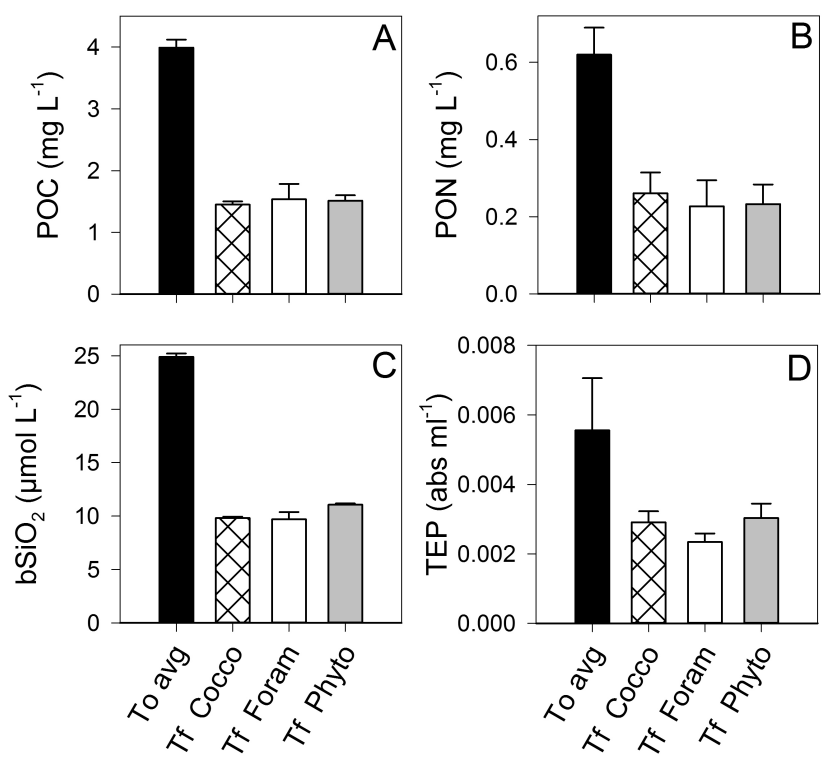

Fig. 5. Concentrations of suspended (A) $\mathrm{POC},(\mathbf{B}) \mathrm{PON},(\mathbf{C}) \mathrm{bSiO}_{2}$, and (D) TEP at the beginning of the experiment $\left(\mathrm{T}_{\mathrm{o}}\right.$, representing an average of all three treatments) and at the end of the experiment $\left(T_{f}\right.$, representing an average of the replicate tanks for each treatment).

a relationship between sinking speed and ESD of $\mathrm{W}=210$ $(\mathrm{ESD})^{0.54}\left(r^{2}=0.55\right)$.

The Foram (w/foram) aggregates, essentially just foraminiferan tests with a small amount of attached particulate organic matter dragging along behind them, sank both the most rapidly (up to $700 \mathrm{~m} \mathrm{~d}^{-1}$ ) and the most rapidly for their size. A clear relationship between sinking speed and ESD was not observed for the Foram (w/foram) aggregates, however. This may have been due to the difficulty of discerning differences in the ESD of particles this small and irregularly sized as the result of the variably sized clump of organic matter adhered to their leeward side. Variability in the POC/PIC ratio due to small differences in the amount of adhered organic matter may also have helped to obscure the relationship between ESD and sinking speed in the Foram (w/foram) aggregates.

\section{Discussion}

\subsection{Influence of coccoliths on the formation, size, and compactness (porosity) of aggregates in the rolling tanks}

The addition of high concentrations of suspended ballast minerals $\left(0.1\right.$ to $\left.1000 \mathrm{mg} \mathrm{L}^{-1}\right)$ to rolling tanks that already contain aggregates results in the fragmentation of those aggregates into a set of smaller, more numerous, and more compact aggregates with minerals now incorporated within them (Passow and De La Rocha, 2006; De La Rocha et al., 2008). Similarly high concentrations of suspended minerals when present during the formation of aggregates also results in notably smaller, more numerous, and more compact mineralcontaining aggregates than would have formed in the absence of those minerals as a result of collisions due to differential settling velocities (Ploug et al., 2008; Engel et al., 2009b; Iversen and Ploug, 2010; Passow et al., 2014).

In this experiment, too, smaller aggregates were formed in the presence of high concentrations of minerals, although this is more clear from measures of the amount of POC, $\mathrm{PON}$, and $\mathrm{bSiO}_{2}$ per aggregate (Fig. 3) than of the measured size of the aggregates. The average ESD of the Cocco aggregates $(4.3 \pm 1.3 \mathrm{~mm})$ is similar to that of the Phyto aggregates $(4.9 \pm 2.0 \mathrm{~mm})$, although the Cocco aggregates spanned a slightly narrower size distribution with proportionally fewer larger aggregates than was the case with the Phyto aggregates. As Fig. 2 shows, $95 \%$ of the Cocco aggregates fell within the 2 to $6.5 \mathrm{~mm}$ ESD range while $95 \%$ of the Phyto aggregates fell within the range of 2 to $9 \mathrm{~mm}$ (n.b. these ESDs are typical of aggregates formed in the upper ocean (Jackson et al., 1997)). The average volume of Cocco aggregates, calculated as for prolate spheroids from the measured length and width of the aggregates, was $0.025 \pm 0.016 \mathrm{~cm}^{3}$ for the Cocco aggregates but $0.055 \pm 0.078 \mathrm{~cm}^{3}$ for the Phyto aggregates.

Contrary to expectations, the Cocco aggregates were not measurably more compact than the Phyto aggregates and the Foram (no foram) aggregates that were lacking calcium carbonate. The average porosity $(P)$ of the aggregates may be calculated (Alldredge and Gottschalk, 1988) as

$P=1-\frac{\mathrm{DW} / \rho}{V}$,

where DW is the dry weight, $\rho$ is the average density of the solid materials making up the aggregate (i.e. organic matter, biogenic silica, and calcium carbonate), and $V$ is the volume of the aggregate. Based on the biogenic silica and calcium carbonate measured per aggregate and assuming that biogenic silica weighed $60 \mathrm{~g} \mathrm{~mol}^{-1}$ and had a density of $2.6 \mathrm{~g} \mathrm{~cm}^{3}$ (Smayda 1970), calcium carbonate weighed $100 \mathrm{~g} \mathrm{~mol}^{-1}$ and had a density of $2.8 \mathrm{~g} \mathrm{~cm}^{3}$ (Smayda 1970), and that all dry weight that was not silica or calcium carbonate was particulate organic matter with an average density of $1.06 \mathrm{~g} \mathrm{~cm}^{3}$ (a typical value for diatom cytoplasm; Smayda (1970)), the average porosity calculate for the Phyto and Foram (no Foram) aggregates was $99.6 \pm 0.08 \%$ and $99.3 \pm 0.2 \%$, respectively, compared to $99.4 \pm 0.05 \%$ for the Cocco aggregates. Given the dense concentration of particulate organic matter in the rolling tanks (nearly $4 \mathrm{mg} \mathrm{L}^{-1}$; Fig. 5), a greater amount of coccolith calcite may have been needed for significant compaction of the Cocco aggregates to have occurred.

In addition to the effect of minerals on aggregate size and compaction, previous work has noted that addition of high concentrations of ballast minerals can trigger (earlier) aggregation in a system (Hamm 2002; Le Moigne et al., 2013) in 
part by increasing the frequency of collisions between particles (Burd and Jackson, 2009). There has always been a temptation to extrapolate this observation to meaning that high concentrations of ballast minerals result in a greater overall amount of aggregation, but it is far from clear that this is the case. Whether or not minerals affect the extent of aggregation (as opposed to just the timing) likely depends on the situation (or design of the experiment). This experiment here suggests that, under conditions already conducive to aggregation, the addition or minerals does not result in more organic matter ending up in aggregates. In each rolling tank in this experiment, $37 \%$ to $38 \%$ of the POC in suspension at $\mathrm{T}_{0}$ had become incorporated into aggregates by the end of the $48 \mathrm{~h}$ experiment regardless of whether the tank contained an added $4.6 \mathrm{mg} \mathrm{L}^{-1}$ of calcite (and regardless of the form of the calcite added) (Fig. 5). Likewise, the amount of $\mathrm{PON}, \mathrm{bSiO}_{2}$, and TEP incorporated into aggregates in the different treatments was essentially the same (Fig. 5) even while, necessarily given the experimental design, the amount of PIC contained in aggregates varied greatly between treatments (Figs. 4 and 7).

There have been a small number of other experiments that report data for the percent of POC that wound up being incorporated into aggregates during the experiment. The numbers reported are both similar and different to the $37 \%$ to $38 \%$ reported here and does not appear to be related to the initial concentration of POC in the experiments. For example, by the end of the 8 day experiment of Le Moigne et al. (2013), which contained coccolith and no-coccolith treatments plus the added complication of live microzooplankton, $40 \%$ of the total POC at the end of the experiment existed incorporated into aggregates. These aggregates were composed of Skeletonema marinoi, Chaetoceros gracilis, and, in some experiment treatments, cleaned coccoliths and/or the marine rotifer, Brachionus sp. This experiment was carried out several months earlier than the one reported here, at a lower initial concentration of suspended POC $\left(\sim 2 \mathrm{mg} \mathrm{L}^{-1}\right)$, and at the lower calcium carbonate concentration (in the tanks to which it was added) of $1.3 \mathrm{mg} \mathrm{L}^{-1}$. But it was conducted in the same rolling tanks on the same roller tables as the experiment presented in this paper. In contrast, a different experiment, run at $1.2 \mathrm{mg} \mathrm{L}^{-1}$ POC in another laboratory, observed $59 \%$ of the POC from a mixture of seawater, cultures of Thalassiosira weissflogii and Chaetoceros affinis, and sea urchin fecal pellets becoming incorporated into aggregates within 48 hours, this time regardless of the $\mathrm{pCO}_{2}$ or suspended clay concentration within the rolling tanks (Passow et al., 2014).

The exact extent of aggregation in the rolling tanks represents an equilibrium between aggregation and disaggregation in a closed container from which sinking particles cannot escape and thus they continue to participate in the aggregation process after a time when, in the ocean, they would have been exported out of the mixed layer. Despite this caveat, it remains striking that the extent of POC incorporation into aggregates within each of the experiments above was inde-
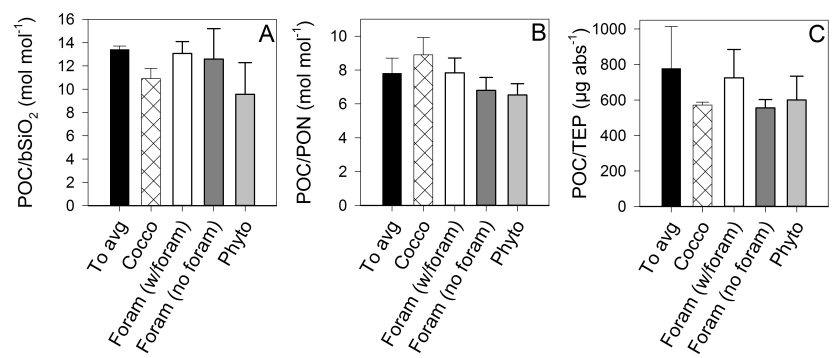

Fig. 6. The ratios of (A) $\mathrm{POC}$ to $\mathrm{bSiO}_{2}$, (B) POC to PON, and (C) POC to TEP in suspension at $\mathrm{T}_{0}$ (the value reported represents an average of the $\mathrm{T}_{0}$ samples for all three treatments) and in the aggregates at the end of the experiment.

pendent of the size and number of aggregates that formed and of whether or not extraneous minerals (clay or calcite) were added. If interaction between particulate organic matter (POM) and sticky particles like TEP controls the overall extent of aggregation, it is interesting that added mineral particles neither enhanced nor diminished the amount of POM that TEP could bind into aggregates. This is even more interesting in light of the clear effect the minerals have in terms of enhancing the susceptibility of the aggregates to fragmentation (Fig. 1) (Passow and De La Rocha, 2006; De La Rocha et al., 2008). Following this thought in a slightly different direction, it would be interesting to know the extent to which a given concentration of TEP results in a predictable amount of incorporation of POC into the aggregate phase. Is it predictable, or is the potential predictability overwhelmed by the variability in the composition, size, numerical abundance (not the same thing as concentration as measured as xanthan gum equivalents), and "stickiness" of TEP in the surface ocean?

Interestingly, TEP in this experiment was not preferentially incorporated into aggregates relative to $\mathrm{POC}$ or $\mathrm{bSiO}_{2}$. The mean POC/TEP ratios for aggregates in the different treatments (Fig. 6) are indistinguishable from one another (ANOVA; $\alpha=0.05 ; p=0.07$ ) as are the mean $\mathrm{bSiO}_{2} /$ TEP ratios (ANOVA; $\alpha=0.05 ; p=0.10$ ). The mean POC/TEP ratios of the aggregates are also indistinguishable from those of the material initially suspended in the rolling tanks and of the material remaining in suspension at the end of the experiment (ANOVA; $\alpha=0.05 ; p=0.08$ ).

This is not what Engel et al. (2002) observed for aggregates formed during a diatom bloom in nutrient-amended unfiltered seawater in an indoor mesocosm. When aggregates began forming on day 16 of their experiment, their POC / TEP ratio was generally higher than that of the background water of the mesocosm. At first glance, this suggests preferential exclusion of TEP from aggregates. It is more likely that photosynthesis by phytoplankton in the aggregates added POC while TEP in the aggregates may have been more easily accessible than phytoplankton POC and thus was preferentially consumed by bacteria and microzooplankton. 
Photosynthesis and preferentially grazing on TEP were not possibilities in the roller tank experiments reported here, as they were conducted in darkness and using filtered seawater in part to avoid such complexity.

\subsection{Impact of foraminiferan tests on aggregate size}

Contrary to expectations, a small clump of particulate organic matter remained associated with each rapidly sinking foraminiferan test (Figs. 3 and 7). In keeping with the expectation, however, that aggregates containing foraminiferan tests would sink too quickly to be stable or long-lived, most of the aggregates that formed within the Foram tanks did not have foraminiferan tests incorporated within them. The large number and small size of these Foram (no foram) aggregates was caused by their frequent collisions with very rapidly sinking foraminiferan tests. These collisions did not result in the incorporation of a foraminiferan test into a Foram (no foram) aggregate, but in the expulsion of some POM from the Foram (no foram) aggregates. Thus a typical collision reduced the size of the Foram (no foram) aggregate by splitting it into one slightly smaller and one very much smaller Foram (no foram) aggregate, both of which would sink more slowly than the original, slightly larger, Foram (no foram) aggregate (Fig. 8). Although such fragmentation of aggregates by sinking foraminiferan tests may also occur in the ocean, diminishing sinking fluxes of POC (the opposite of the ballast effect) by fragmenting marine snow into smaller, more slowly sinking forms, the destructive effect of the foraminiferan tests was amplified in the confine of the rolling tanks over the $48 \mathrm{~h}$ duration of the experiment.

As a point of comparison to our suggestion that fastsinking foraminiferan tests more inhibit than promote the export of organic matter from the upper ocean, it is both worth noting that two recent studies have suggested that organic matter may be exported from the surface ocean in association with extremely large protist cells and worth noting that neither of these studies may be relevant to the effects of the foraminiferan tests reported here. In the first case, fluxes of acantharian cysts made of the dense mineral celestite (strontium sulfate) contained significant internal quantities of organic matter and thus served as a major vector of organic matter flux out of the surface ocean (Martin et al., 2010). In the second case, unidentified protists (but putatively radiolarians, which produce an internal skeleton of silica and are embedded in a gelatinous matrix) were collected in the North Atlantic associated with fast sinking material (Riley et al., 2012). Unfortunately, whether the large, unidentified protist cells noted in this second study contained biominerals was not ascertained, presumably because a prohibitively small amount of material was collected during the study. Further work, primarily in the field, is needed to determine whether or not large, dense, fast sinking tests, either empty or still associated with the cellular matter of the large pro- tist, enhance or diminish sinking fluxes of POC in aggregates formed through coagulation.

\subsection{Sinking speeds}

As with previous studies, the sinking speeds of aggregates in this experiment were related to both the size and composition of the aggregates (Ploug et al., 2008; Engel et al., 2009b; Iversen and Ploug, 2010). In keeping with expectations, larger aggregates sank faster, and aggregates laden with coccolith ballast sank faster than similarly sized aggregates that lacked this additional ballast (Fig. 8).

The relationship between ESD and sinking speed for the Phyto aggregates and the Foram (no foram) aggregates plotted along the same trend (sinking speed $=70(\mathrm{ESD})^{1.00}$ ). This reflects that the Phyto and the Foram (no foram) aggregates had essentially the same composition (diatom POM plus $\mathrm{bSiO}_{2}$ ballast in the form of diatom frustules but no added calcite ballast). This is unsurprising as they were formed over the same time period from the same starting culture of Chaetoceros gracilis. The only real difference between the Phyto aggregates and the Foram (no foram) aggregates is their average ESD; the Foram (no foram) aggregates are smaller because of fragmentation during collisions with the rapidly sinking foramninferan tests, as described in Sect. 4.2.

The faster sinking of the Cocco aggregates for their ESD compared to the Phyto and Foram (no foram) aggregates can be mainly ascribed to their increase in excess density from the incorporation of coccoliths into the aggregates. Another possibility for increasing the sinking speed would have been a decrease in porosity such as is known to occur with aggregates heavily laden with mineral particles (De La Rocha and Passow, 2007). The decrease in porosity likely reduced the fluid flow through aggregates and therefore the drag experienced by the aggregate as it sinks. However, as there was no calculable difference in the porosity of the Cocco and the Phyto or Foram (no foram) aggregates (see Sect. 4.1), a decrease in porosity could not contribute to the faster sinking speeds of the Cocco aggregates in this experiment.

This relationship between ESD and sinking speed for the Phyto and Foram (no foram) aggregates is steeper than measured for aggregates of Skeletonema costatum formed in notably smaller rolling tanks $(1.15 \mathrm{~L})$ by Iversen and Ploug (2010) (Fig. 8). Likewise, the Cocco aggregates from this experiment also show a steeper relationship between ESD and sinking speed than the $S$. costatum plus coccolith-bearing Emiliania huxleyi aggregates of Iversen and Ploug (2010) (Fig. 8). The sinking speeds of the S. costatum aggregates were measured via a different method, by suspending them in a known vertical, diffuse flow of water (Ploug and Jorgensen, 1999). Although the sedimentation column method used here tends to yield slightly higher estimates of sinking speed than the flow system (Ploug et al., 2010), the differences in the estimates are too great to be solely ascribed to this. It is more likely that they relate 

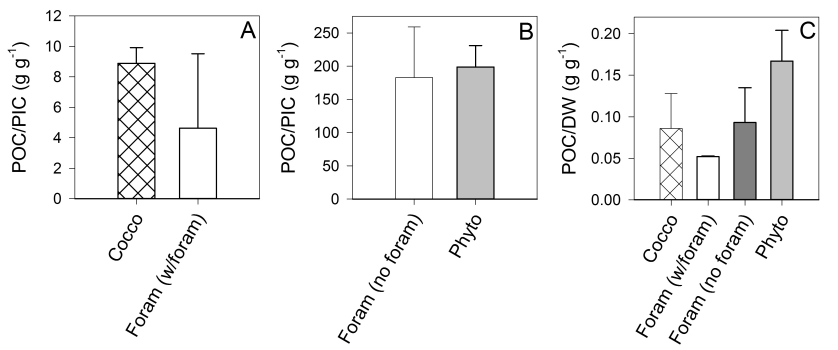

Fig. 7. Ratios of POC / PIC in (A) calcite-containing aggregates and in (B) aggregates lacking calcite and ratios of (C) POC to dry weight in all aggregates.

to differences in the character and composition of the aggregates such as their shape, porosity, wet density, and the amount of $\mathrm{bSiO}_{2}$ ballasting (diatoms of different species or grown under different conditions have vastly different ratios of POC to $\mathrm{bSiO}_{2}$ ). Different techniques used to size the aggregates prior to the sinking speed measurement may have also contributed to the different ESD versus sinking speed slopes.

On this same note, the sinking speeds versus ESD for all but most of the Foram (w/foram) aggregates in this experiment were slower (Fig. 8) than those reported for aggregates of benthic fluff, bacteria, and S. costatum (Ziervogel and Forster, 2005). The aggregates of Zievogel and Forster (2005), however, containing mainly material resuspended from the seafloor, contained a very notable quantity of minerals, as indicated by the excess density (over seawater) of these aggregates of $8 \mathrm{mg} \mathrm{cm}^{-3}$. The excess density of aggregates in this experiment (calculate from dry weight to volume ratios, and the wet density of the material in the aggregates) was notably lower, at $0.7 \mathrm{mg} \mathrm{cm}^{-3}$ for the Phyto aggregates, $0.6 \mathrm{mg} \mathrm{cm}^{-3}$ for the Foram (no foram) aggregates, and $4.5 \mathrm{mg} \mathrm{cm}^{-3}$ for the Cocco aggregates.

\subsection{Geographic context}

To begin to extrapolate the results of this laboratory study to the ocean, we must note that the distributions of coccolithophores and forams are not uniform throughout the oceans, and thus the importance of the reported effects of coccoliths and large planktonic foraminiferan tests on aggregate character and sinking should also not be uniform throughout the ocean.

Coccolithophores have a cosmopolitan distribution, but they are clearly more abundant in some areas than others (Brown and Yoder, 1994; Iglesias-Rodriguez et al., 2002; Alvain et al., 2008). Immense coccolithophore blooms may form during the growing season in the North Atlantic, the region of the ocean most intensely dominated by coccolithophore biomass. Smaller scale coccolithophore blooms are also important in places like the Baltic Sea, the Bering Sea, and parts of the Southern Ocean. Based on the maps

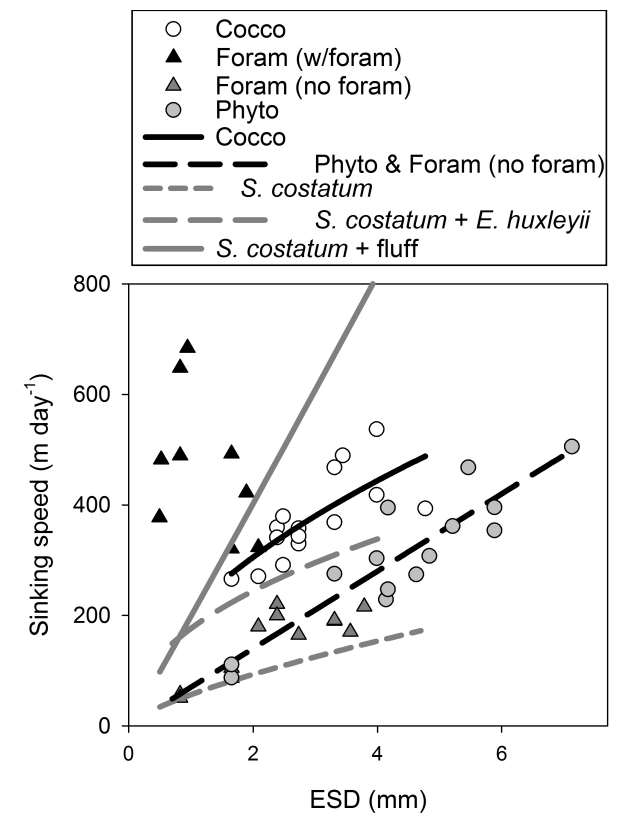

Fig. 8. Sinking speeds versus size (equivalent spherical diameter) of the different types of aggregates formed in this experiment. The solid curves shown for the aggregates from this experiment are $y=21(\mathrm{ESD})^{0.54}$ for the Cocco aggregates $\left(r^{2}=0.55\right)$, and $y=$ 70 (ESD) ${ }^{1.00}$ for the Phyto and the Foram (no foram) aggregates taken together $\left(r^{2}=0.82\right)$. The dotted and the dashed lines show for comparison the relationships reported for Skeletonema costatum aggregates and aggregates of a mixture of $S$. costatum and Emiliania huxleyi by Iversen and Ploug (2010) and for aggregates of $S$. costatum mixed with resuspended fluff from the seafloor (Ziervogel and Forster, 2005).

that have been produced of coccolithophore distributions and abundance (Brown and Yoder, 1994; Iglesias-Rodriguez et al., 2002; Alvain et al., 2008), aggregates in the North Atlantic would be the ones with the greatest tendency to experience fragmentation, compaction, and elevated sinking speeds due to ballasting by coccoliths. This is also a region where overall ballasting by biogenic silica is relatively unimportant, based on the low concentrations of silicic acid in surface waters and relatively low fluxes of biogenic silica into deep sea sediment traps (Honjo et al., 2008). Overall, the transport efficiency (François et al., 2002) of export production to the deep sea in the North Atlantic ranges from low (averaging $0.5 \%$ in the polar regions of the North Atlantic) to middling (averaging $6 \%$ in the North Atlantic drift) (Honjo et al. 2008).

Planktonic forams, in contrast, are not resoundingly more present in one ocean basin versus another (Schiebel, 2002). Instead, they tend to be more abundant where there is an abundant supply of primary production to support the growth of zooplankton. Thus relatively high abundances of planktonic forams are found along ocean margins and in the Antarctic Circumpolar Current, resulting in an export of 
$10-35 \mathrm{~g} \mathrm{~m}^{-2} \mathrm{y}^{-1}$ of $\mathrm{CaCO}_{3}$ at $100 \mathrm{~m}$ from these regions. Their highest abundances occur in coastal upwelling zones and result in an export of $35-90 \mathrm{~g} \mathrm{~m}^{-2} \mathrm{y}^{-1}$ of $\mathrm{CaCO}_{3}$ at $100 \mathrm{~m}$ from these regions (Schiebel, 2002). Thus the most intensive production of the potentially disruptive planktonic foraminiferan tests occurs exactly in the areas where intense, episodic growth of phytoplankton blooms favors the export of POC in aggregates.

The margins of the North Atlantic Ocean (i.e. the North Sea, the Baltic Sea, and between Greenland and Iceland) represent an area of overlap between the areas of intense coccolithophore bloom and the areas of high abundances of planktonic forams, especially as abundances of both types of calcite-producing organisms would peak during the phytoplankton growth season. But the release of individual foraminiferan tests following gametogenesis (when foraminiferan organic matter is generally given over to the gametes) generally occurs at a few hundred metres depth within the ocean, potentially deeper than the regions of the epipelagic and upper mesopelagic where the highest concentrations of aggregates occur, vertically separating the areas where the effects of coccoliths and the effects of foraminiferan tests would be important.

\section{Conclusions}

This experiment has confirmed a simple principle, that different physical forms of calcium carbonate (e.g. coccoliths versus planktonic foraminiferan tests) could have significantly different effects on the export of POC from the surface ocean to the deep sea. These differences need to be considered if PIC fluxes are used to estimate or improve estimates of POC sinking fluxes into the deep sea and would help to explain regional variability in the relationship between POC and PIC sinking fluxes (Wilson et al., 2012).

Individual coccoliths, such as shed by coccolithophores, become efficiently incorporated into aggregates. Although at high concentrations they may reduce the size and mass of aggregates through compaction and fragmentation, their incorporation into aggregates results in higher sinking speeds (Fig. 8). In this experiment, they neither enhanced nor inhibited the total transfer of suspended POC into aggregates. Overall, coccoliths should increase the export of POC by increasing its sinking velocity, improving its chances of sinking out of the surface ocean before being oxidized back to $\mathrm{CO}_{2}$ and nutrients.

Large foraminiferan tests, on the other hand, sink so rapidly, they are not an efficient vector for the export of POC from the surface ocean. During the experiment, foraminiferan tests became associated with $\mathrm{POC}$ at a ratio of roughly $5 \mathrm{~g}$ of POC per gram of PIC compared to coccoliths' $9 \mathrm{gg}^{-1}$ at the same overall PIC concentration and ratio to total POC (Fig. 7). Thus while any POC associated with foraminiferan tests would sink more rapidly out of the surface ocean than that incorporated into aggregates containing coccoliths (Fig. 8), it would take a much greater mass of foraminiferan calcite than coccolith calcite per gram of POC to be hastened out of the surface ocean. In addition, any aggregates struck by a rapidly sinking foraminiferan test would be potentially fragmented into two more slowly sinking particles.

Acknowledgements. We thank A. Masson and M.-L. Rouget for assistance with analyses and two anonymous reviewers for helpful comments. This work was funded by EURO-BASIN (no. 264933), an Integrating Project of the European Community $7^{\text {th }}$ Framework Programme.

Edited by: C. Heinze

\section{References}

Alldredge, A. L. and Gotschalk, C.: In situ settling behavior of marine snow, Limnol. Oceeanogr. 33, 339-351, 1988.

Alldredge, A. L. and Silver, M. W.: Characteristics, dynamics and significance of marine snow, Prog. Oceanogr., 20, 41-82, 1988.

Alvain, S., Moulin, C., Dandonneau, Y., and Loisel, H.: Seasonal distribution and succession of dominant phytoplankton groups in the global ocean: A satellite view, Global Biogeochem. Cy., 22, GB3001, doi:10.1029/2007GB003154, 2008.

Antia, A. N., Koeve, W., Fischer, G., Blanz, T., Schulz-Bull, D., Scholten, J., Neuer, S., Kremling, K., Kuss, J., Peinert, R., Hebbeln, D., Bathmann, U., Conte, M., Fehner, U., and Zeitschel, B.: Basin-wide particulate carbon flux in the Atlantic Ocean: regional export patterns and potential for atmospheric $\mathrm{CO}_{2}$ sequestration, Global Biogeochem. Cy., 15, 845-862, 2001.

Armstrong, R. A., Lee, C., Hedges, J. I., Honjo, S., and Wakeham, S. G.: A new, mechanistic model for organic carbon fluxes in the ocean based on the quantitative association of POC with ballast minerals, Deep-Sea Res. Pt.II, 49, 219-236, 2002.

Boyd, P. W. and Trull, T. W.: Understanding the export of biogenic particles in oceanic waters: Is there consensus?, Prog. Oceanogr., 72, 276-312, 2007.

Broecker, W. S.: Ocean chemistry during glacial time, Geochim. Cosmochim. Acta, 46, 1689-1705, 1982.

Brown, C. W. and Yoder, J. A.: Coccolithophorid blooms in the global ocean, J. Geophys. Res., 99, 7467-7482, 1994.

Burd, A. B. and Jackson, G. A.: Particle aggregation, Annu. Rev. Mar. Sci., 1, 65-90, 2009.

De La Rocha, C. L. and Passow, U.: Factors influencing the sinking of POC and the efficiency of the biological carbon pump, DeepSea Res. Pt.II, 54, 639-658, 2007.

De La Rocha, C. L., Nowald, N., and Passow, U.: Interactions between diatom aggregates, minerals, particulate organic carbon, and dissolved organic matter: Further implications for the ballast hypothesis, Global Biogeochem. Cy., 22, GB4005, doi:10.1029/2007GB003156, 2008.

Deuser, W. G., Ross, E. H., and Anderson, R. F.: Seasonality in the supply of sediment to the deep Sargasso Sea and implications for the rapid transfer of matter to the deep ocean, Deep Sea Res. A, 28, 495-505, 1981. 
Ebersbach, F., Trull, T. W., Davies, D. M., and Bray, S. G.: Controls on mesopelagic particle fluxes in the Sub-Antarctic and Polar Frontal Zones in the Southern Ocean south of Australia in summer - Perspectives from free-drifting sediment traps, DeepSea Res. Pt.II, 58, 2260-2276, 2011.

Engel, A., Goldthwait, S., Passow, U., and Alldredge, A.: Temporal decoupling of carbon and nitrogen dynamics in a mesocosm diatom bloom, Limnol. Oceanogr., 47, 753-761, 2002.

Engel, A., Abramson, L., Szlosek, J., Liu, Z., Stewart, G., Hirschberg, D., and Lee, C.: Investigating the effect of ballasting by $\mathrm{CaCO}_{3}$ in Emiliania huxleyi: II. Decomposition of particulate organic matter, Deep-Sea Res. Pt.II, 56, 1408-1419, 2009a.

Engel, A., Szlosek, J., Abramson, L., Liu, Z., and Lee, C.: Investigating the effect of ballasting by $\mathrm{CaCO}_{3}$ in Emiliania huxleyi: I. Formation, settling velocities and physical properties of aggregates, Deep-Sea Res. Pt.II, 56, 1396-1407, 2009 b.

Fischer, G. and Karakas,, G.: Sinking rates and ballast composition of particles in the Atlantic Ocean: implications for the organic carbon fluxes to the deep ocean, Biogeosciences, 6, 85102, doi:10.5194/bg-6-85-2009, 2009.

François, R., Honjo, S., Krishfield, R., and Manganini, S.: Factors controlling the flux of organic carbon to the bathypelagic zone of the ocean, Global Biogeochem. Cy., 16, 1087, doi:10.1029/2001GB001722, 2002.

Guidi, L., Jackson, G. A., Stemmann, L., Miquel, J. C., Picheral, M., and Gorsky, G.: Relationship between particle size distribution and flux in the mesopelagic zone, Deep-Sea Res. Pt.I, 55, 1364 1374,2008

Guillard, R. R. L.: Culture of marine phytoplankton for feeding marine invertebrates, in: Culture of Marine Invertebrate Animals, edited by: Smith, W. L. and Chanley, M. H., Plenum Press, New York, 26-60, 1975.

Hamm, C. E.: Interactive aggregation and sedimentation of diatoms and clay-sized 700 lithogenic material, Limnol. Oceanogr., 47, 1790-1795, 2002.

Harlay, J., Chou, L., De Bodt, C., Van Oostende, N., Piontek, J., Suykens, K., Engel, A., Sabbe, K., Groom, S., Delille, B., and Borges, A. V.: Biogeochemistry and carbon mass balance of a coccolithophore bloom in the northern Bay of Biscay (June 2006), Deep-Sea Res. Pt.I, 58, 111-127, 2011.

Honjo, S., Manganini, S. J., Krishfield, R. A., and François, R.: Particulate organic carbon fluxes to the ocean interior and factors controlling the biological pump: A synthesis of global sediment trap programs since 1983, Prog. Oceanogr., 76, 217-285, 2008.

Iglesias-Rodriguez, D., Brown, C. W., Doney, S. C., Kleypas, J., Kolber, D., Kolber, Z., Hayes, P. K., and Falkowski, P. G.: Representing key phytoplankton functional groups in ocean carbon cycle models: Coccolithophorids, Global Biogeochem. Cy., 16, 1100, doi:10.1029/2001GB001454, 2002.

Iversen, M. H. and Ploug, H.: Ballast minerals and the sinking carbon flux in the ocean: carbon-specific respiration rates and sinking velocity of marine snow aggregates, Biogeosciences, 7 , 2613-2624, doi:10.5194/bg-7-2613-2010, 2010.

Iversen, M. H., Nowald, N., Ploug, H., Jackson, G. A., and Fischer, G.: High resolution profiles of vertical particulate matter export off Cape Blanc, Mauritania: Degradation processes and ballasting effects, Deep Sea Res. Pt.I, 57, 711-784, 2010.

Jackson, G. A., Maffione, R., Costello, D. K., Alldredge, A. L., Logan, B. E., and Dam, H. G.: Particle size spectra between
$1 \mu \mathrm{m}$ and $1 \mathrm{~cm}$ at Monterey Bay determined using multiple instruments, Deep-Sea Res. Pt.I 44, 1739-1767, 1997.

Kiørboe, T.: Formation and fate of marine snow: small-scale processes with large-scale implications, Sci. Mar. 65, 57-71, 2001.

Klaas, C. and Archer, D. E.: Association of sinking organic matter with various types of mineral ballast in the deep sea: Implications for the rain ratio, Global Biogeochem. Cy., 16, 1116, doi:10.1029/2001GB001765, 2002.

Kwon., E. Y., Primeau, F., and Sarmiento, J. L.: The impact of remineralization depth on the air-sea carbon balance, Nature Geosci., 2, 630-635, 2009.

Le Moigne, F. A. C., Gallinari, M., Laurenceau, E., and De La Rocha, C. L.: Enhanced rates of particulate organic matter remineralization by microzooplankton are diminished by added ballast minerals, Biogeosciences, 10, 5755-5765, 2013, http://www.biogeosciences.net/10/5755/2013/.

Lorrain, A., Savoye, N., Chauvaud, L., Paulet, Y.-M., and Naulet, N.: Decarbonation and preservation method for the analysis of organic $\mathrm{C}$ and $\mathrm{N}$ contents and stable isotope ratios of lowcarbonated suspended particulate material, Anal. Chim. Acta, 491, 125-133, 2003.

Martin, J. H., Knauer, G. A., Karl, D. M., and Broenkow, W. W.: VERTEX: carbon cycling in the northeast Pacific, Deep-Sea Res., 34, 267-285, 1987.

Martin, P., Allen, J. T., Cooper, M. J., Johns, D. G., Lampitt, R. S., Sanders, R., and Teagle, D. A. H.: Sedimentation of acantharian cysts in the Iceland Basin: Strontium as a ballast for deep ocean particle flux, and implications for acantharian reproductive strategies, Limnol. Oceanogr. 55, 604-614, 2010.

McDonnell, A. M. P. and Buesseler, K. O.: Variability in the average sinking velocity of marine particles, Limnol. Oceanogr., 55 , 2085-2096, 2010.

Mullin, J. B. and Riley, J. P.: The spectrophotometric determination of silicate-silicon in natural waters with special reference to sea water, Anal. Chim. Acta, 46, 491-501, 1965.

Passow, U.: Switching perspectives: do mineral fluxes determine particulate organic carbon fluxes or vice versa?, Geochem. Geophys. Geosyst., 5, Q04002, doi:10.1029/2003GC000670, 2004.

Passow, U. and Alldredge, A. L.: Aggregation of a diatom bloom in a mesocosm: The role of transparent exopolymer particles (TEP), Deep-Sea Res. Pt.II, 42, 99-109, 1995.

Passow, U. and De La Rocha C. L.: Accumulation of mineral ballast on organic aggregates, Global Biogeochem. Cy., 20, GB1013, doi:10.1029/2005GB002579, 2006.

Passow, U., De La Rocha, C. L., Fairfield, C., and Schmidt K.: Aggregation as a function of $\mathrm{pCO}_{2}$ and mineral particles, Limnol Oceanogr., in press, 2014.

Ploug, H. and Jorgensen, B. B.: A net-jet flow system for mass transfer and microsensor studies of sinking aggregates, Mar. Ecol. Prog. Ser., 176, 279-290, 1999.

Ploug, H., Iversen, M. H., and Fischer, G.: Ballst, sinking velocity, and apparent diffusivity within marine snow and zooplankton fecal pellets: Implications for substrate turnover by attached bacteria, Limnol. Oceanogr. 53, 1878-1886, 2008.

Ploug, H., Terbrüggen, A;, Kaufmann, A., Wolf-Gladrow, D., and Passow, U.: A novel method to measure particle sinkig velocity in vitro, and its comparison to three other in vitro methods, Limnol. Oceanogr.: Methods, 8, 386-393, 2010. 
Poulton, A. J., Sanders, R., Holligan, P. M., Stinchcombe, M. C., Adey, T. R., Brown, L., and Chamberlain, K.: Phytoplankton mineralization in the tropical and subtropical Atlantic Ocean, Global Biogeochem. Cy., 20, GB4002, doi:10.1029/2006gb002712, 2006.

Ragueneau, O. and Tréguer, P: Determination of biogenic silica in coastal waters: applicability and limits of the alkaline digestion method, Mar. Chem., 45, 43-51, 1994.

Riley, J. S., Sanders, R., Marsay, C., Le Moigne, F. A. C., Achterberg, E. P., and Poulton, A. J.: The relative contribution of fast and slow sinking particles to ocean carbon export, Global Biogeochem. Cy., 26, GB1026, doi:10.1029/2011GB004085, 2012.

Sanders, R., Morris, P. J., Poulton, A. J., Stinchcombe, M. C., Charalampopoulou, A., Lucas, M. I., and Thomalla S. J.: Does a ballast effect occur in the surface ocean?, Geophys. Res. Lett., 37, L08602, doi:10.1029/2010GL042574, 2010.

Schiebel, R.: Planktic foraminiferal sedimentation and the marine calcite budget, Global Biogeochem. Cy., 16, 1065, doi:10.1029/2001GB001459, 2002.

Shanks, A. L. and Trent, J. D.: Marine snow - Sinking rates and potential role in vertical flux, Deep-Sea Res. A, 27, 137-143, 1980.
Smayda, T. J.: The suspension and sinking of phytoplankton in the sea, Oceanogr. Mar. Biol. Ann. Rev., 8, 353-414, 1970.

Suess, E.: Particulate organic carbon flux in the oceans-surface productivity and oxygen utilization, Nature, 288, 260-263, 1980.

Thomalla, S. J., Poulton, A. J., Sanders, R., Turnewitsch, R., Holligan, P. M., and Lucas, M. I.: Variable export fluxes and efficiencies for calcite, opal, and organic carbon in the Atlantic Ocean: A ballast effect in action?, Global Biogeochem. Cy., 22, GB1010, doi:10.1029/2007GB002982, 2008.

Turner, J. T.: Zooplankton fecal pellets, marine snow and sinking phytoplankton blooms, Aquat. Microb. Ecol., 27, 57-102, 2002.

Wilson, J. D., Barker, S., and Ridgwell, A.: Assessment of the spatial variability in particulate organic matter and mineral sinking fluxes in the ocean interior: Implications for the ballast hypothesis, Global Biogeochem. Cy., 26, GB4011, doi:10.1029/2012GB004398, 2012.

Ziervogel, K. and Forster, S.: Aggregation and sinking behaviour of resuspended fluffy layer material, Cont. Shelf Res., 25, 18531863, 2005. 